\title{
Geomorphological Evaluation of Weathering on the Marine Scarp of Um Sid Plateau in South Sinai, Egypt
}

\author{
Manal Samir Shalapy Metwaly*
}

\begin{abstract}
Both the internal and external environments have cooperated so that weathering plays a main role in weakening the marine scarp rock of Um Sid Plateau in the south of Sharm El-Sheikh. It was formed from limestone rocks which are the most responsive to disintegration and dissolution. In addition, the increase in porosity, sulfate and chloride salts increases disintegration. This has resulted in several geomorphological phenomena including ones related to chemical weathering and another related to mechanical weathering. The rock fall hazard is one of the most important problems resulting from the weathering in Um Sid Plateau which caused a direct risk on the human activities which occur beneath it. The study relied on several petro physical, chemical and microscopic analyses to know the features of weakness and their influence on the scarp. [Bul. Soc. Géog. d'Égypte, 2020, 93: 81-114]
\end{abstract}

Key Words: Weathering, Laboratory analyses; Marine scarp, Hazards.

\section{Introduction}

Weathering, with its two types; chemical and mechanical is one of the formation factors of marine precipice. It plays a main role in weakening rocks and in preparing them to the other erosion factors especially if the cliffs consist of limestone (Raheel, 2019). This is because chemical weathering plays an outstanding role in the processes of decomposition, dissolution and collapse of rocks. However, mechanical weathering plays its role in the processes of expansion and contraction and moisturizing and drying. These processes result in the weakening and disintegration of rocks.

The Marine Scarp of Um Sid plateau is located in the western south of Sharm El Sheikh city between the two latitudes of $27^{\circ} 50^{\prime}$ and $27^{\circ} 51^{\prime} \mathrm{N}$, and between the two longitudes of $34^{\circ} 17^{\prime}$ and $34^{\circ} 19^{\prime} \mathrm{E}$. Its length extends to $5.3 \mathrm{~km}$ (Figure 1). Its height ranges from less than one meter to $30 \mathrm{~m}$ above the sea-level with an average slope of $33^{\circ}$, noting that it reaches $90^{\circ}$ in several locations.

* Lecturer of Geomorphology and Geographical Information System, Faculty of Arts, Port Said University, Egypt.

For Correspondence: e-mail: Manal.samir@ arts.psu.edu.eg 
The study aims to observing the physical and human factors which affect the activity of weathering, studying their resulting geomorphological phenomena, the resulting hazards, and the methods of facing and reducing them. Therefore, a number of analyses are used including the petro physical and hydro chemical analyses, the Thin-Section and the scanning electronic microscope. They are used to evaluate weathering with its two types'; the chemical and mechanical.

- Previous Studies: Many authors studied the weathering such as (Abdel-Halim, et al 2007), (El-Mahary, 2007), (Youssef, 2009), (Abd El-Megeed, 2012), (Salama, 2016), (Eladawy, et al., 2017), (Saber, 2017), (Gharbi, et al., 2018), (Manasrah, et al., 2019).

- Lab Studies and Results: This study aims to answer the following two questions:

1. What is the extent of response of the Marine Scarp to the weathering process?

2. Is the role of weathering a main or secondary one in the formation and retreat of the Scarp after the erosion factors especially the sea ones?

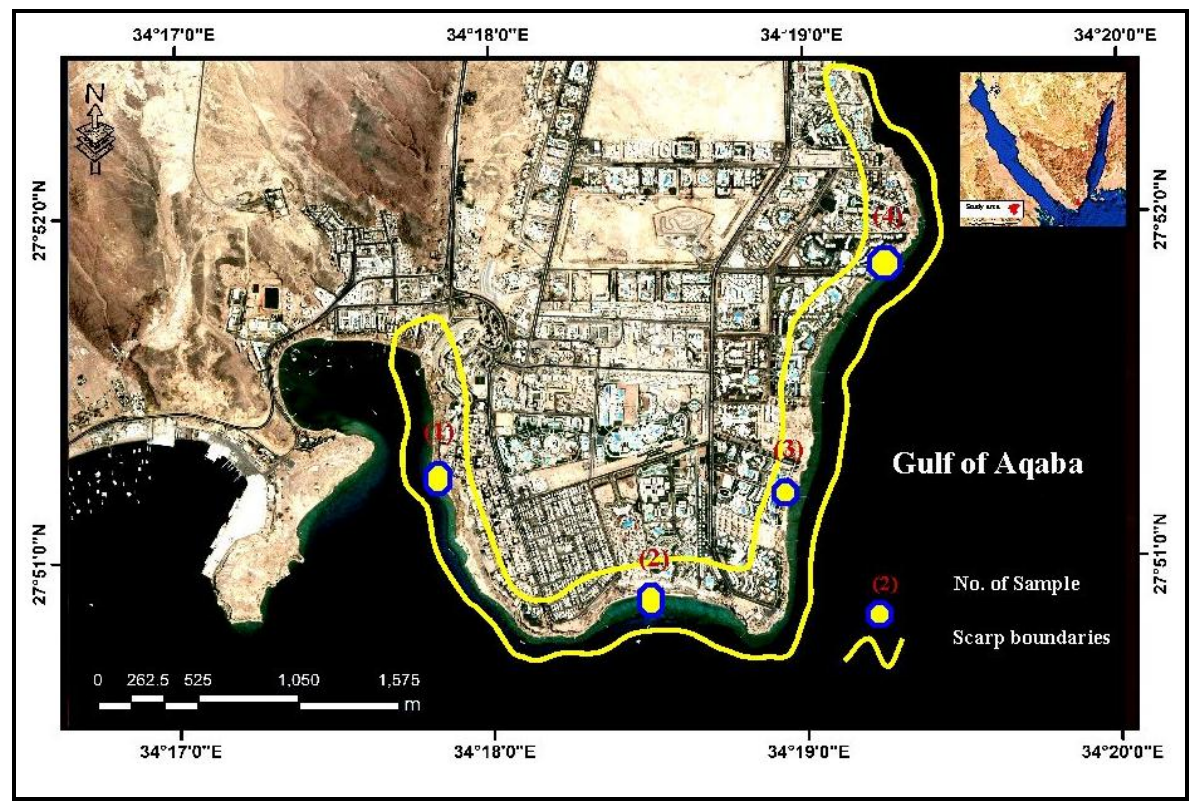

Source: Topographic maps scale 1: 50000 (1991) and Google Earth (2020).

Figure 1. The Marine Scarp of Um Sid plateau and the location of rock samples. 
To achieve the research objectives, four samples of the scarp rocks were taken where the degree of response of the rocks to weathering was identified (SSI) Salt susceptibility index (Table 1); based on the classification set by Yu and Oguchi, 2010 (Appendix 1).

Table (1) analysis reveals that the Marine Scarp rocks of Um Sid Plateau have a high and very high degree of response to weathering especially in the southern side of the Scarp which exceeded 16. Accordingly, the internal environment represented in the chemical and physical characteristics of the rocks is very suitable for the activity of the weathering process especially with the availability of the variable external environment including the climate conditions, sources of humidity (sea water- rain- relative humidity- irrigation water-sewage), salts (sea water) which had a great role in increasing the activity of weathering. Thus, the internal and external environments have collaborated so that weathering achieves a main role in the dissociation, disintegration, and decomposition of the Scarp rocks in the light of the weakness of the other erosion factors especially the sea ones. Accordingly, the subject deserves studying to know the role of weathering in the formation and retreat of the Marine Scarp of Um Sid Plateau.

Table 1. The degree of response of the Marine Scarp rocks of Um Sid Plateau to weathering.

\begin{tabular}{|l|c|c|l|}
\hline $\begin{array}{c}\text { No. of } \\
\text { Sample }\end{array}$ & Location to the Scarp & $\begin{array}{c}\text { The } \\
\text { degree }\end{array}$ & \multicolumn{1}{|c|}{ Classification } \\
\hline 1 & West & 14.54 & Very salt prone \\
\hline 2 & South & 16.2 & Exceptionally salt prone \\
\hline 3 & East & 12.92 & Very salt prone \\
\hline 4 & East & 13.59 & Very salt prone \\
\hline The average & $--\cdot-\cdot--$ & 14.3 & Very salt prone \\
\hline
\end{tabular}

Source: laboratory analysis in the Egyptian General Petroleum Co.

To achieve the aim of the study, its subjects were classified as follows:

\section{First:}

The affective factors in the weathering process in the Marine Scarp of Um Sid plateau:

\section{1) The Climatic Factors:}

Studying the climatic characteristics is one of the important factors as they affect the weathering processes and their rate in the area of study which can be handled as follows in (Table 2): 


\section{A. Temperature:}

The analysis of Table (2) clarifies that the annual rate of temperature in Sharm El Sheikh Station reached $25.7{ }^{\circ} \mathrm{C}$, August is the highest month in temperature with a monthly rate of $32.9^{\circ} \mathrm{C}$ while January is the lowest month in temperature with a monthly rate of about $17.6^{\circ} \mathrm{C}$. This resulted in a rise in the thermal range in the area of study as it ranges from 8.2 to $10.7^{\circ} \mathrm{C}$.

Table 2. The climatic characteristics in Sharm El-Sheikh station 1982-2010.

\begin{tabular}{|l|c|c|c|c|c|}
\hline \multicolumn{1}{|c|}{ Months } & $\begin{array}{c}\text { Temperature } \\
\left({ }^{\circ} \mathrm{C}\right)\end{array}$ & $\begin{array}{c}\text { Thermal } \\
\text { Range }\left({ }^{\circ} \mathrm{C}\right)\end{array}$ & $\begin{array}{c}\text { Relative } \\
\text { Humidity }(\mathbf{\%})\end{array}$ & $\begin{array}{c}\text { Evaporation } \\
(\mathbf{m m})\end{array}$ & $\begin{array}{c}\text { Perception } \\
(\mathbf{m m})\end{array}$ \\
\hline December & 19.2 & 8.2 & 47 & 11.7 & 12.4 \\
\hline January & 17.6 & 8.5 & 44 & 11.1 & 0.5 \\
\hline February & 18.2 & 8.8 & 41 & 13.2 & 0.2 \\
\hline March & 21 & 9.1 & 41 & 14.7 & 1 \\
\hline April & 25 & 9.8 & 37 & 17.6 & 0.03 \\
\hline May & 29 & 10.4 & 35 & 21 & 0.4 \\
\hline June & 31.8 & 10.6 & 33 & 26.8 & 0 \\
\hline July & 32.5 & 10.7 & 36 & 25 & 0 \\
\hline August & 32.9 & 9.6 & 38 & 22.6 & 0 \\
\hline September & 31 & 9.1 & 41 & 21.1 & 0.03 \\
\hline October & 27.6 & 8.2 & 46 & 16.4 & 1 \\
\hline November & 23 & 8.3 & 47 & 13 & 0.6 \\
\hline The Average & $\mathbf{2 5 . 7}$ & $\mathbf{9 . 3}$ & $\mathbf{4 0 . 5}$ & $\mathbf{1 7 . 9}$ & Total/16.2 \\
\hline
\end{tabular}

Source: Egyptian Metrological Authority.

The previous studies reveal the rise of the seasonal rate of insolation in the study area (10.1 hour/day) noting that this high rate of insolation is not completely received by rocks as some areas are subject to the complete rate while others are sometimes exposed to the direct solar radiation and during the rest of the time they are subject to the sun shade (Saber, 2017). This process leads to a strong heating of rocks during the day. At night, however, rocks lose their heat quickly. No doubt this variation in temperature has affected the process of mechanical weathering directly as it led to the widening of joints, cracks and slight rifts which are spread in the rocks of the study area. The block becomes subject to separation and breaks into small ones In addition, the exposed parts stretch so that stresses are exerted inside rocks and lead to the separation of slight slides paralleling the surface. With the continuity of this process, rocks weaken and disintegrate into varied size granules as spread in the study area. 


\section{B. Humidity:}

The analysis of Table (2) clarifies that the rates of humidity in both winter and autum are high ones as the two months of November and December have registered the highest monthly average with the percentage of $47 \%$ while the lowest monthly average was that of June (33\%). As to the annual average of humidity, it was $40.5 \%$. With the decrease in relative humidity and the rise in temperature in summer, the rates of evaporation increase and result in the increasing the rates of dehydration; this helped in activating the processes of rock dissociation as a result of mechanical weathering. As to the condition in winter, the availability of an amount of humidity and the reduction in temperature helped in activating the process of chemical weathering. This led to the conversion of the basic minerals which constitute the rocks into other minerals with very weak resistance to the erosion factors.

\section{Evaporation:}

Evaporation is one of the important influential factors in the process of weathering. The analysis of Table (2) reveals the increase in the rates of evaporation in the area of study as the annual rate of evaporation in Sharm El-Sheikh Station has reached $17.88 \mathrm{~mm}$. June is the highest month in the evaporation level throughout the year $(26.8 \mathrm{~mm})$ and this results in the deposition of the Halite mineral in the form of a slight layer of salts causing pressures on rocks that end with their dissociation.

\section{Perception:}

Perception plays an important role in the process of weathering despite the little amount of rain in the area of study in general. The perception on the slopes help in increasing water pressure in the pores and in accelerating the movement of materials on the surface of slopes (Saber, 2017). Table (2) shows that there is no rain in summer while the quantity of winter rain is $31.1 \mathrm{~mm}$. Despite the decrease in the quantity of rain and its irregularity in the area of study, the concentration of rain falling in winter, the month of temperature reduction, increases the effectiveness of these little quantities so that the leaking of rain waters into Um Sid Plateau across its spread cracks and pores increases its water content and the growth of plants, leading to the increase in the activity of the weathering process especially the chemical one. In addition, the hazards of perception lie in the interaction of their constituents with the rock ones since the Carbonic acid becomes dissolved in the rain waters and converted into the Carbonic acid solution and the Calcium Carbonate $\mathrm{CaCO}_{3}$ spread in the area of study becomes converted into Calcium Bicarbonate $\mathrm{Ca}$ $\left(\mathrm{HCO}_{3}\right)_{2}$ that is dissolved in water. This resulted in the increase of the 
processes of dissociation, decomposition and weakness in the rock minerals constituting Um Sid Plateau.

Out of all that has been said, it is obvious that several climatic factors collaborate in weakening rocks and accelerate their response to the processes of mechanical and chemical weathering so that the Marine Scarp of Um Sid Plateau becomes exposed to disintegration and decomposition. These features have contributed in creating the convenient conditions for the activity of the other erosion factors especially the sea ones.

\section{2) The Characteristics of Sea Waters:}

\section{A. Waves:}

Waves in the study area are of a medium height since the average of their height is $53 \mathrm{~cm}$ (Abd El-Mageed, 2012). This is because of the existence of coral reefs in the form of a strip in front of the coast of the area of study and which limits the speed and height of waves and then breaks and decreases their speed.

Waves affect the Scarp of the Plateau directly through hitting the rocks and penetrating inside the cracks and joints on the front of the Plateau and lead to the entrapment a pressuring of air inside them. When the waves bounce, the air expands inside the cracks causing an explosive effect (Mahsoub, 1991). This results in the expansion in these cracks and joints and accordingly, the weakness of the rock formation, its shattering and the undermining and collapse of cliffs located along the face of the Scarp. However, waves affect the Scarp of the Plateau indirectly through the splash of the waves' water resulting from colliding violently with the Scarp. It is characterized with the high level of salt especially Sodium Chlorides which result in the deposition of the Halite mineral (Sodium Chloride) in the form of a slight crust of salts and result in the increase of the rates of chemical weathering.

\section{B. Tides:}

Table (3) reveals that the average difference between the high and low tides during winter months has reached $1.7 \mathrm{~m}$ since the winter season is the highest month in the water levels of the high tide which reached $1.2 \mathrm{~m}$, while the summer season has registered the lower water levels of the high tide $0.96 \mathrm{~m}$. This variation between the high and low tides reflects the existence of weathering action process in the lower part of the Marine Scarp of Um Sid Plateau especially the chemical weathering because of the sea water. This is obvious in the rock formation in the area of study especially 
the limestone formations which constitute the study area and which appear in a dark colour reflecting the interaction of the sea water with the minerals constituting the rocks (Figure 2).

\section{The Physical and Chemical Characteristics of the Sea Water:}

Physical and chemical characteristics of the sea water play a major role in the activity of the weathering process since the high rate of salinity leads to the weakness of the rocks which constitute the Scarp. This is because it converts its original minerals into minerals with new and different chemical characteristics.

Table 3. The monthly averages of the water levels of high and hazard tides in Sharm El Sheikh in the Period from 2008 to 2010.

\begin{tabular}{|c|c|c|}
\hline Month & Average high tide & Average low tide \\
\hline January & 1.33 & -0.44 \\
\hline February & 1.225 & -0.426 \\
\hline March & 1.24 & -0.449 \\
\hline April & 1.234 & -0.44 \\
\hline may & 1.152 & -0.335 \\
\hline June & 1.119 & -0.335 \\
\hline July & 1.01 & -.037 \\
\hline august & 0.93 & -0.26 \\
\hline September & 0.969 & -0.15 \\
\hline October & 1.07 & -0.278 \\
\hline November & 1.165 & -0.376 \\
\hline December & 1.246 & -0.45 \\
\hline Average & 1.14 & -0.36 \\
\hline
\end{tabular}

Source: (Aabd El-Megeed, 2012, p. 153)

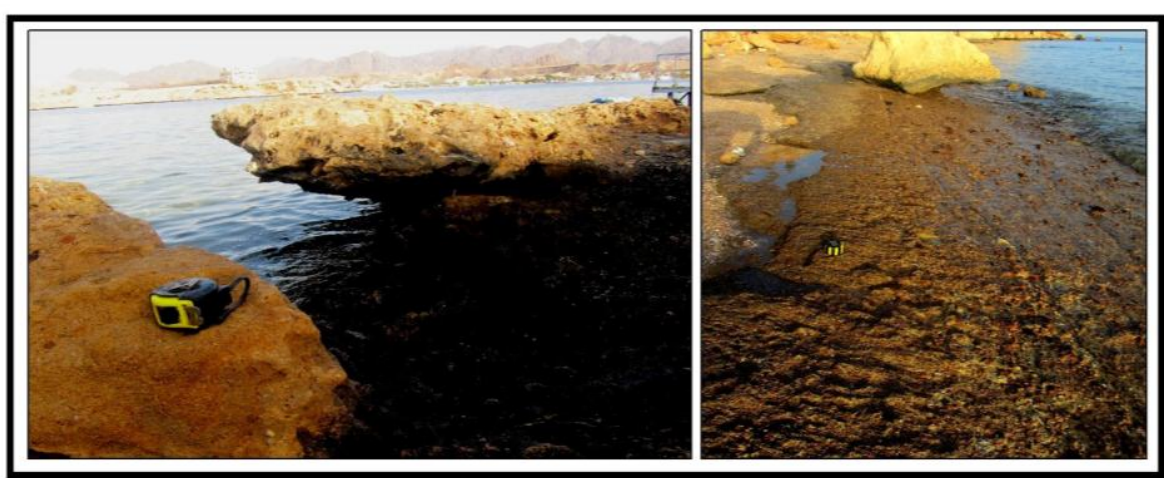

Source: Field study, 2019.

Figure 2. The appearance of limestone formations with a dark colour reflecting the interaction between the sea water and the minerals constituting the rocks. 
The previous studies reveal that the general average of temperature in the Gulf of Aqaba in the south of the scarp of the Um Sid Plateau has reached $25.72^{\circ}$ and it reached $26.11^{\circ}$ in its northern side (Abdel-Halim et al., 2007). This denotes that there is a temperature reduction towards the south and that it affected the weathering action through dissolving some of the minerals and rocks in hazard temperature, this is because Carbon dioxide dissolves in water constituting Carbonic acid which interacts with the Calcium Carbonate, the main constituent of Um Sid Plateau, to produce the dissolvable Calcium Bicarbonate. This explains the dissolution activity along the marine scarp of the Plateau especially the southern and western sides respectively.

The analysis of Table (4) shows the rise in the degree of salinity in the Gulf of Aqaba in front of the study area since it reached $48400 \mathrm{mg} / \mathrm{L}$ with the rise in the rates of Sodium ions and chlorides and an obvious decrease in the Potassium ions, Bicarbonates and Calcium. The general average of the $\mathrm{PH}$ value in the study area has reached 8.20. It is observable that its rise is related to the rise in the salinity and temperature rates. Accordingly, the chemical characteristics of the Gulf of Aqaba water have an important role in the rise of the total dissolved salts in the rocks' minerals which results in the activation of the two processes of decomposition and dissolution especially that the marine scarp of Um Sid Plateau consists of limestone.

Table 4. Chemical properties of the waters of the Gulf of Aqaba.

\begin{tabular}{|l|c|}
\hline \multicolumn{1}{|c|}{ Chemical Properties } & Concentration Degree (mg/L) \\
\hline T.D.S & 48400 \\
\hline $\mathrm{Na}$ & 14150 \\
\hline $\mathrm{Ca}$ & 500 \\
\hline $\mathrm{Mg}$ & 1620 \\
\hline $\mathrm{K}$ & 370 \\
\hline $\mathrm{CL}$ & 27500 \\
\hline $\mathrm{SO}_{4}$ & 3800 \\
\hline $\mathrm{HCO}_{3}$ & 122 \\
\hline
\end{tabular}

Source: Laboratory nalysis at the Faculty of Engineering, Zagazig University.

Analyzing the properties of the sea water in front of the marine scarp of Um Sid Plateau reveals that the sea water is an important source of humidity and salts in the study area. It has a direct effect upon $15 \%$ of the height of the marine scarp through waves and tide; sometimes its effect reaches up to $100 \%$ indirectly through the water splash which is carried through waves or wind. This can be verified through the existence of a domain saturated with water in the lower parts of the scarp which touche the sea level and in which chemical and physical interactions are activated. 
This is because the humidity resulting from the sea water is one of the most hazardous factors of physiochemical deterioration as it is a common feature in most of the chemical weathering processes including oxidation, carbonation, dissolution or hydrolysis; especially that it contains high rates of dissolved salts which approached 50 thousand $\mathrm{mg} / \mathrm{L}$ to be carried through pores, cracks and minute rifts whose presence inside rocks results in extreme damage.

\section{3) Geological Setting:}

Geological formations are among the factors which affect the process of weathering since rocks with their variant genesis, shape and rock formation play a great role in specifying the type of the process, the extent of its action and organization of its work. It is worth mentioning that depending on the topographical maps only is considered a general analysis since there is a big difference in the mineral formation of rocks and various differences in their physical and chemical properties. Accordingly, the study has relied on collecting and analyzing samples of the scarp rocks (Table 5).

Table 5. The chemical and petro physical properties of the marine scarp of Um Sid Plateau rocks.

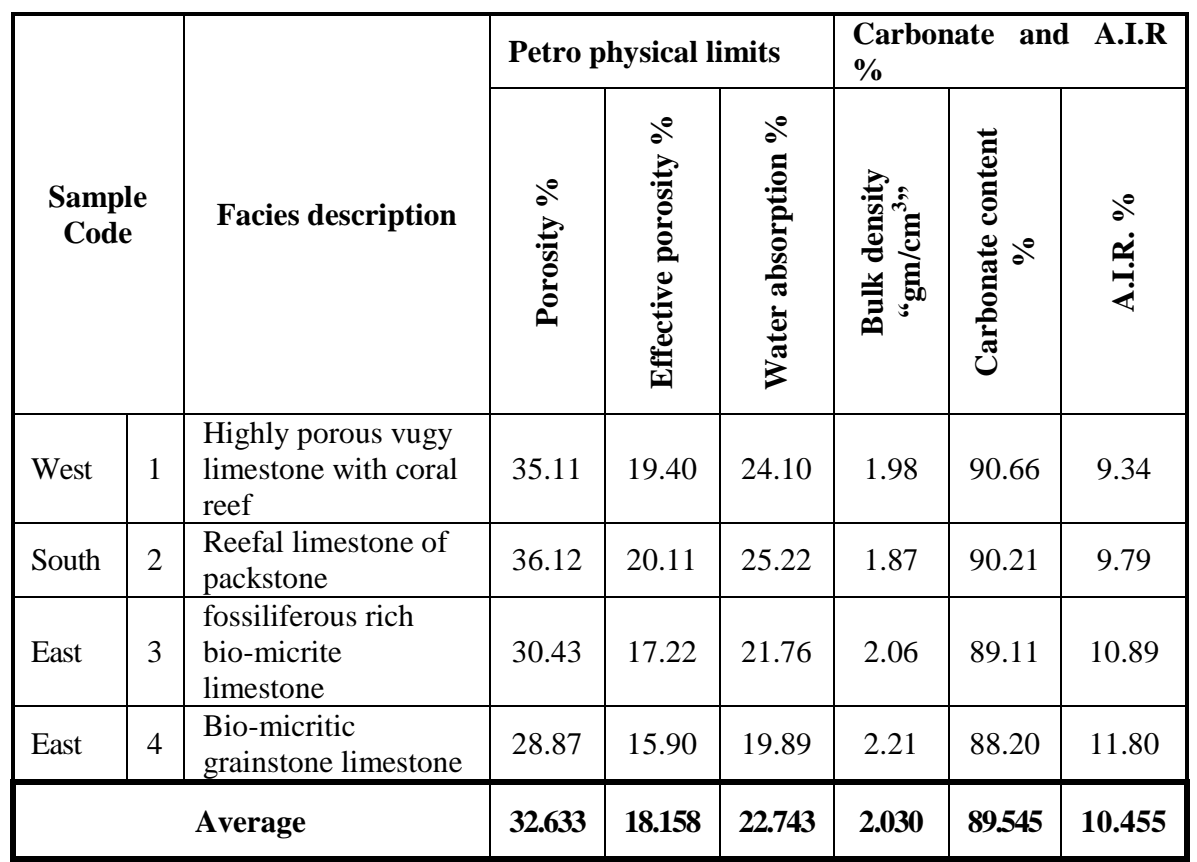

Source: Laboratory analyses: the central laboratories of the Faculty of Engineering, Kafr El-Sheikh University and the central laboratories of the General petroleum Co. 


\section{A. The Chemical Composition and Rock Texture:}

The marine scarp of Um Sid Plateau consists of two units; the first lies in the upper layer and consists of coral limestone, the second lies in the hazarder layer and consists of sandstone with Marl interventions (Figure 3). It is affected by several modern faults which originated at the end of the Paleocene age and whose direction is the northern east and the southern west. As to the ancient faults, they were formed in the Oligocene age and most of them permeate through the sandstone layers and the upper layers are not affected by them (Abd Eltawab, 2012).

The analysis of (Table 5) reveals the rise in the percentage of the Carbonate substances (calcareous substances) in the rocks of the study area since it ranges from 88.20 to $90.21 \%$ especially in the south and west of the scarp where the percentage of Calcium bicarbonate exceeded $90 \%$.It has an obvious effect upon the weakening and deterioration of rocks.

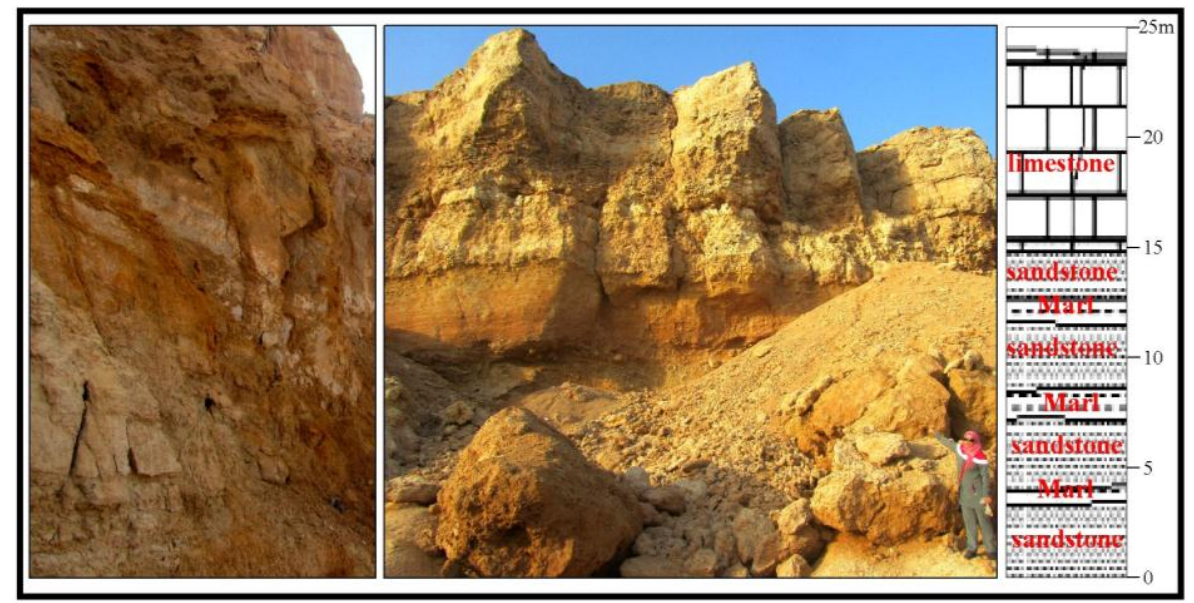

Source: Field Study 2019, and the chemical analysis of rock samples 2019.

Figure 3. The geological formation of the marine scarp of Um Sid Plateau.

The analysis of the samples of the Thin-Section optical microscope with a magnification power of 400X (Figure 4) reveals the spread of limestone consisting of the Micrite in the samples of the scarp. This limestone responds to weathering greatly since these samples are full of fossils, gaps, manifold rifts with salt crystals. This is beside the Calcite mineral, the Micrite, the Microspar and the fossils coloured with Sparite especially in the south and west of the study area. 

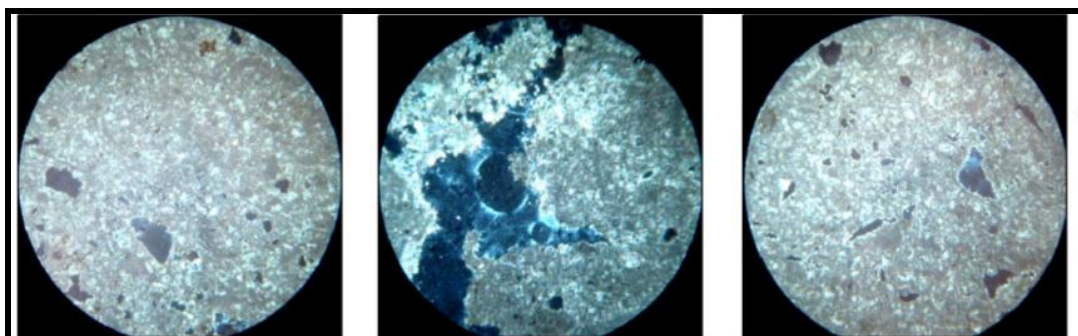

Sample (1)

Micrite with Microspar and gaps in addition to the manifold rifts that weaken the rock texture

A rock consisting of Micrite with Microspar, it hase varid size empty gaps having salt crystals
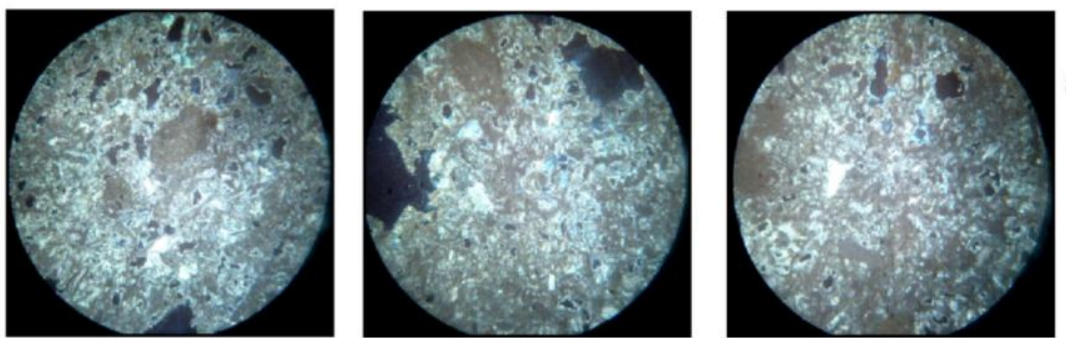

Sample (2)

Limestone with Micrite, some mud minerals, fossils full of sprite and some empty gaps
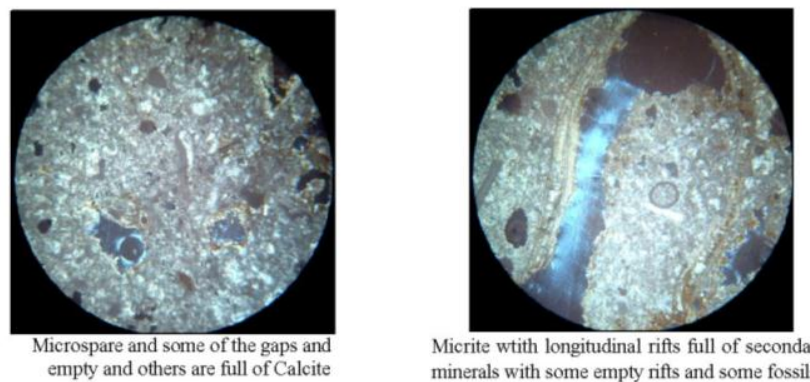

Micrite wtith longitudinal rifts full of secondary minerals with some empty rifts and some fossils
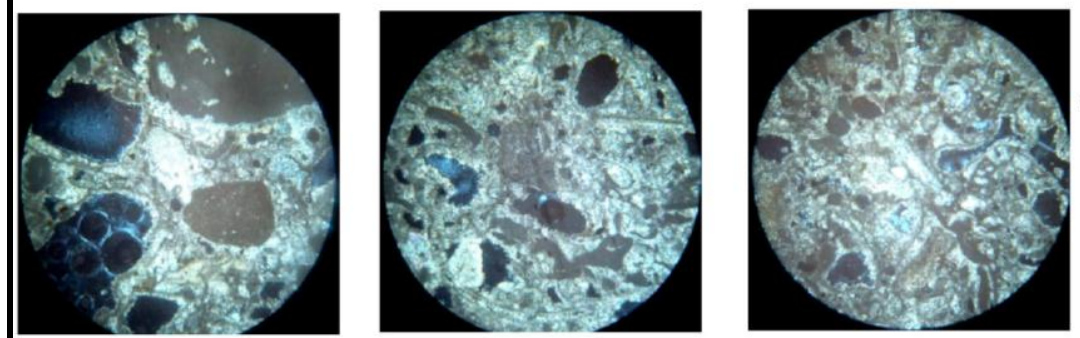

Sample (4)

A limestone consisting of fossils and gaps with some secondary minerals (Calcite)

Source: Laboratory analysis in the Central Laboratory -Faculty of Science Kafr El Sheikh University.

Figure 4. Variation in the mineral structure of the rocks of the marine scarp of Um Sid Plateau. 
Accordingly, all the samples are subject to the weathering action with varied degrees as represented in the multiplicity of pores, cracks and salts. This helped in the activation of chemical weathering action. This is beside the spread of the intersecting and paralleled cracks as well as the crystalizing of Calcite. Moreover, the spread fossils weakens the rocks' resistance and increases the activity and effect of the weathering processes especially in the south of the marine scarp.

\section{B. The Petro physical Properties of Rocks:}

The study of the petro physical properties of rocks is highly important since it represents the structural properties of rocks and therefore helps us in knowing the degree of its resistance to the different weathering factors.

The analysis of Table (5) reveals that the general average of porosity in the samples of the study area has reached $32.63 \%$ which ranged between $28.87 \%$ and $36.12 \%$ since it registered the highest percentage of porosity in the south of the scarp in the study area with a percentage that exceeded $35 \%$. Thus, the percentage of porosity is high in the samples of the study according to the classification of Farmer, 1968; and range between medium to high (Kamh, 2007). This is due to the spread of gaps as they helped in the increase of the porosity of rocks and their ability at absorbing water. This results in the formation of pathways for weathering action with its different forms especially the chemical one. Moreover, the rocks, especially those of the study area, were weakened due to the spread of salt crystals in the gaps as conveyed by the analysis of the Thin-Section microscope (Figure 5).

Table (5) shows that the general average of the degree of rock absorption for water has reached $22.7 \%$ since it ranged between $19.89 \%$ and $25.22 \%$. This denotes that there is a direct relation between the percentage of water absorption and the degree of porosity in the samples of the area rocks which reached 0.98 . Whenever the percentage of porosity increases in rocks, the water absorption and weathering action processes increase as well.

Table (5) shows that there is a general decrease in the density of the study area samples as it reached $22.74 \mathrm{gm} / \mathrm{cm}^{3}$. This denotes that there is a contrastive relationship between the general density and the degree of response of rocks to weathering which reached 0.96 . Whenever density decreases, the response of rocks to weathering increases and therefore, rocks dissociate and collapse. The result of this is that the ability of rocks to bear pressure becomes hazard since the general average of the rock ability to bear pressure became 2.030 (Table 5). This shows that the study area belongs to the hazard pressure category according to the American code of classifying the 
mechanical properties of limestone (Kamh, 2011) and this ensures the fact that the study area rocks have been affected by the weathering processes.
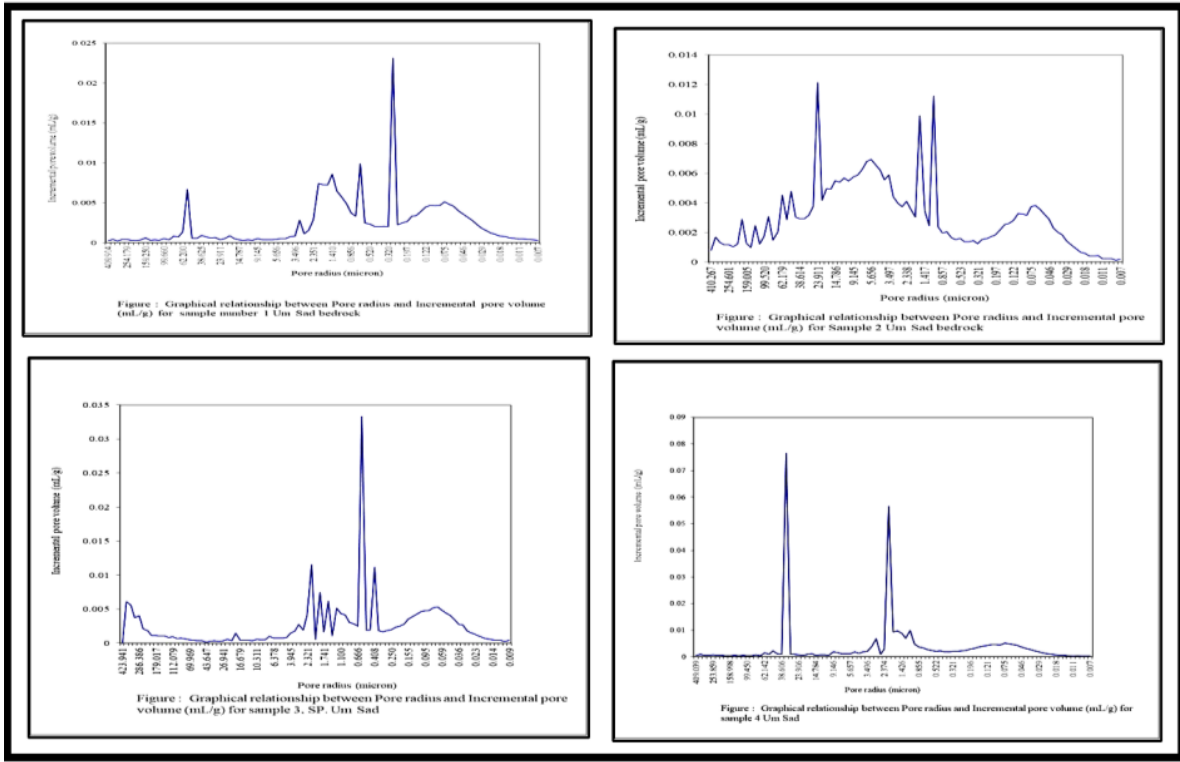

Figure 5. The percentage of the diameters of the rock pores in the study area.

The study relied upon the method of the ultrasonic pulses (Table 6) to confirm the percentage of porosity inside rocks. This method relies on measuring the velocity of ultrasonic waves $\mathrm{Cp}$ and the internal friction force QC to clarify the degree of weathering in each sample since there is a contrastive relationship between them (Figure 6).

Table 6. Ultrasonic waves results.

\begin{tabular}{|l|c|l|c|c|}
\hline \multicolumn{2}{|c|}{$\begin{array}{c}\text { Sample } \\
\text { Code }\end{array}$} & \multicolumn{1}{|c|}{ Facies description } & $\begin{array}{c}\text { C.P.* } \\
\text { "mm/sec" }\end{array}$ & Q.C.* \\
\hline West & 1 & Highly porous vugy limestone with coral reef & 1.72 & 4.35 \\
\hline South & 2 & Reefal limestone of packstone & 1.56 & 4.87 \\
\hline East & 3 & fossiliferous rich bio-micrite limestone & 1.81 & 3.51 \\
\hline East & 4 & Bio-micriticgrainstone limestone & 1.97 & 3.01 \\
\hline \multicolumn{2}{|c|}{ Average } & $\mathbf{1 . 2 7 2 5}$ & $\mathbf{3 . 1 8 2 5}$ \\
\hline
\end{tabular}

Source: Laboratory analysis in the laboratories of the Faculty of Engineering, Kafr El Sheikh University.

* Cp is velocity of ultrasonic waves.

* Qc is rock's internal friction. 


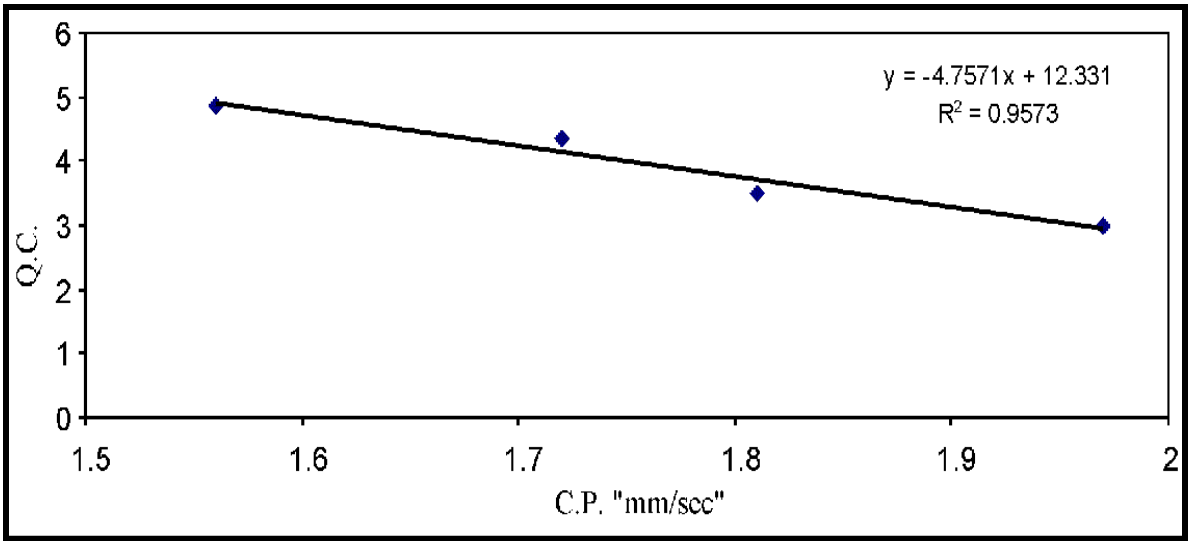

Source: Based on table (6).

Figure 6. The degree of relatedness between the speed of the ultrasound waves and the force of internal friction of the rocks of the marine scarp of Um Sid Plateau.

The analysis of (Table 6) reveals that there is a slight variance in the speed of the ultrasonic waves as it ranged from $1.56 \mathrm{~mm} / \mathrm{sec}$. to 1.97 $\mathrm{mm} / \mathrm{sec}$. with a general average that reached $1.756 \mathrm{~mm} / \mathrm{sec}$. where the general average of the internal friction force has reached 3.94 which ranged between 3.51 and 4.87. This denotes that there is a contrastive relationship between the speed of the ultrasonic waves and the friction force that reached -0.98 . This means that whenever the friction decreases, that is whenever porosity and gaps decreases, the speed of the ultrasonic waves increases and vice versa. We notice a decrease in the speed of the ultrasonic waves and an increase in the friction force. This means that the samples of the study area were affected by the mechanical and chemical weathering processes.

Studying the properties of the marine scarp rocks shows that they consist of limestone which is the most responsive type of rock to dissociation and dissolution because of weathering; especially with the increase in the porosity, the spread of gaps and the formation of pathways to the weathering action which weakened rocks. In addition to the rates of expansion and contraction, this helped in the spread of the entangled rifts, the holes and the gaps. Accordingly, the mineral crystals were distorted because of the pressure resulting from the internal stresses among them so that different size granules were formed in the study area especially in the south and west of the scarp. 


\section{4) The Human Factors:}

Human factors play a distinctive role in the activeness of the weathering process and its effect upon the marine scarp of the Plateau. The Plateau is distinguished with its unique touristic location to Sharm El Sheikh City and the attraction of tourists. This explains the construction of villas with their gardens, swimming pools and touristic resorts (Figure 7). Both the Excessive irrigation of gardens; which is the main characteristic in touristic areas and the sewage leakage into the Plateau-as registered in several locations (Figure 8) have led to the growth of plants inside them especially on the marine scarp (Figure 9). This growth has a mechanical effect as it helps in expanding the joints and cracks, therefore disintegration of rocks. This growth has a chemical effect as it forms organic acids from the rotten plants. These acids have a great effect upon the dissolution of some elements (Saber, 2017). This led to the increase in the porosity, the widening of cracks and joints more and more in the marine scarp so that rocks become increasingly weak, to end in disintegration and decomposition.

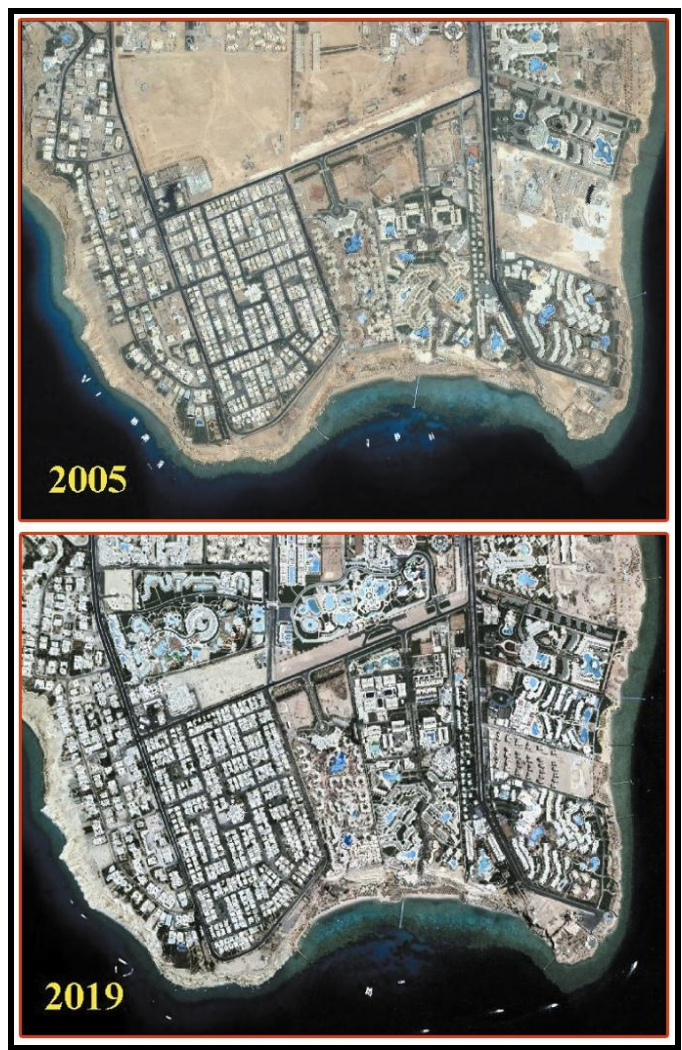

Source: Google Earth.

Figure 7. The spread of touristic resorts, swimming pools and gardens on the surface of Um Sid Plateau. 


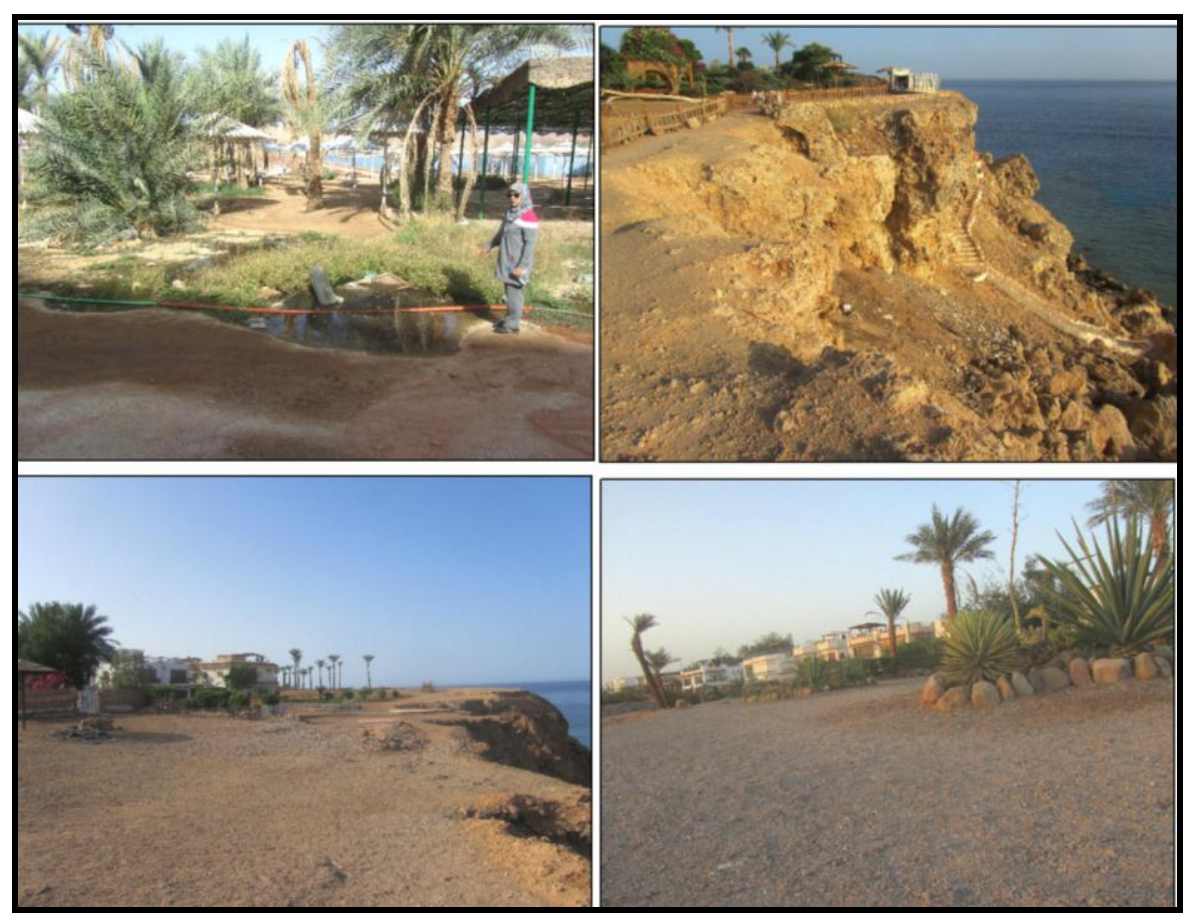

Source: Field study, 2019.

Figure 8. Human activity on the surface of Um Sid Plateau.

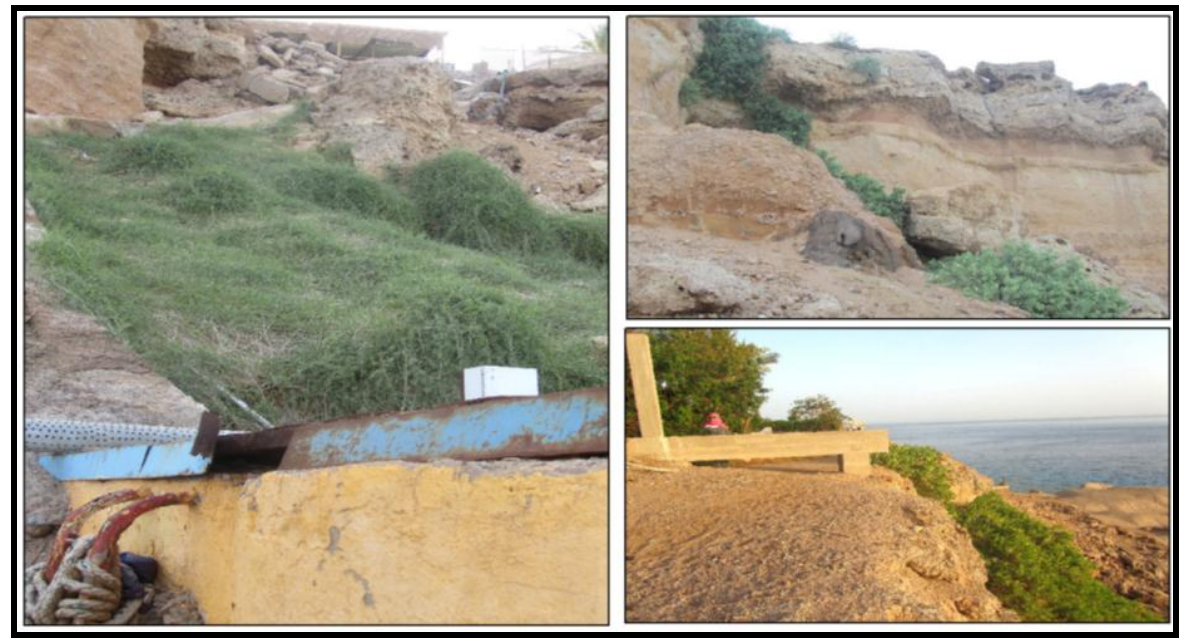

Source: Field study, 2019.

Figure 9. The growth of plants inside the joints and cracks which helped in the dissociation, disintegration and decomposition of the marine scarp rocks of Um Sid Plateau. 
The problem has been worsened with the terrain properties of the Plateau surface since Figure (10) indicates the plainness of its surface evenness as the percentage of the hazard slope areas has reached 94.2\%. This has helped in the increasing and quick growth of human activity on the surface of the Plateau and in the increasing of the water lakage process.

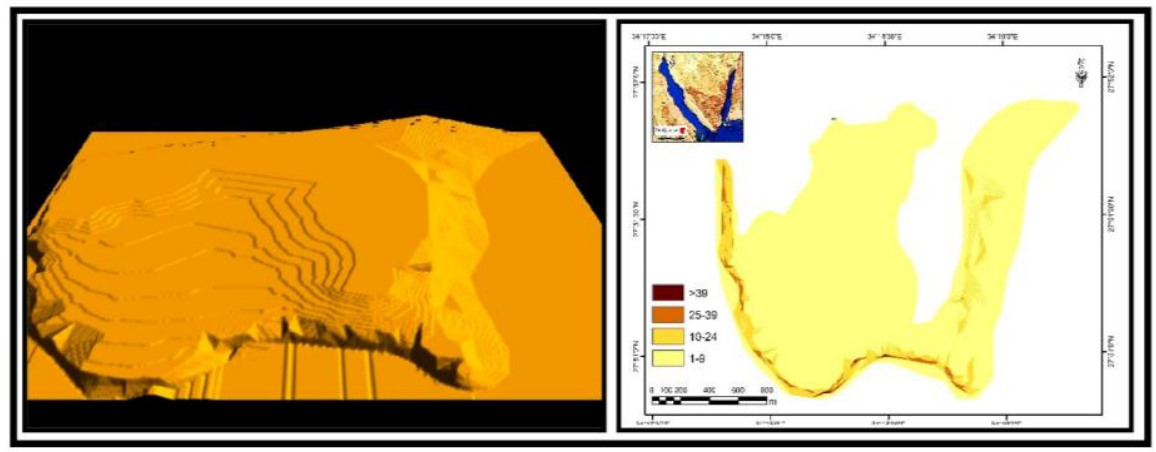

Figure 10. The Slopes degrees and relief model image of Um Sid Plateau surface.

The constituents of the Plateau especially the scarp were dissolved due to the correlation of the natural factors including the spread of limestone and Marl in Um Sid Plateau with the spread of cracks and joints inside it and the evenness of its surface and the human factors including the leakage of irrigation water and sewage as well as the growth of plants inside rifts. The field study revealed the spread of cracks and joints which appeared obviously inside the limestone formation and it ranged between medium and strong especially in the south of the scarp (Figure 11). Generally, joints and cracks are characterized with the existence of several directions whether vertical or horizontal or both, which is the most prevalent. Besides, the degree of intersection is medium to high with big depths.

The persistence of most of these joints ranges between 10 and $20 \mathrm{~m}$. Most of them have steep dip angles varying between 80 and $85^{\circ}$. The joint opening ranges between 0.5 and $10 \mathrm{~cm}$ with rough undulated surfaces (Abd El-Tawab, 2012)

Accordingly, the phenomena of mass separation, shattering and granular disintegration becomes spread so that the size of the dissociated masses increases, sloping increases, the surface of the scarp retreats and several geomorphological phenomena become spread such as holes, cavities and granules (Figure 12). 


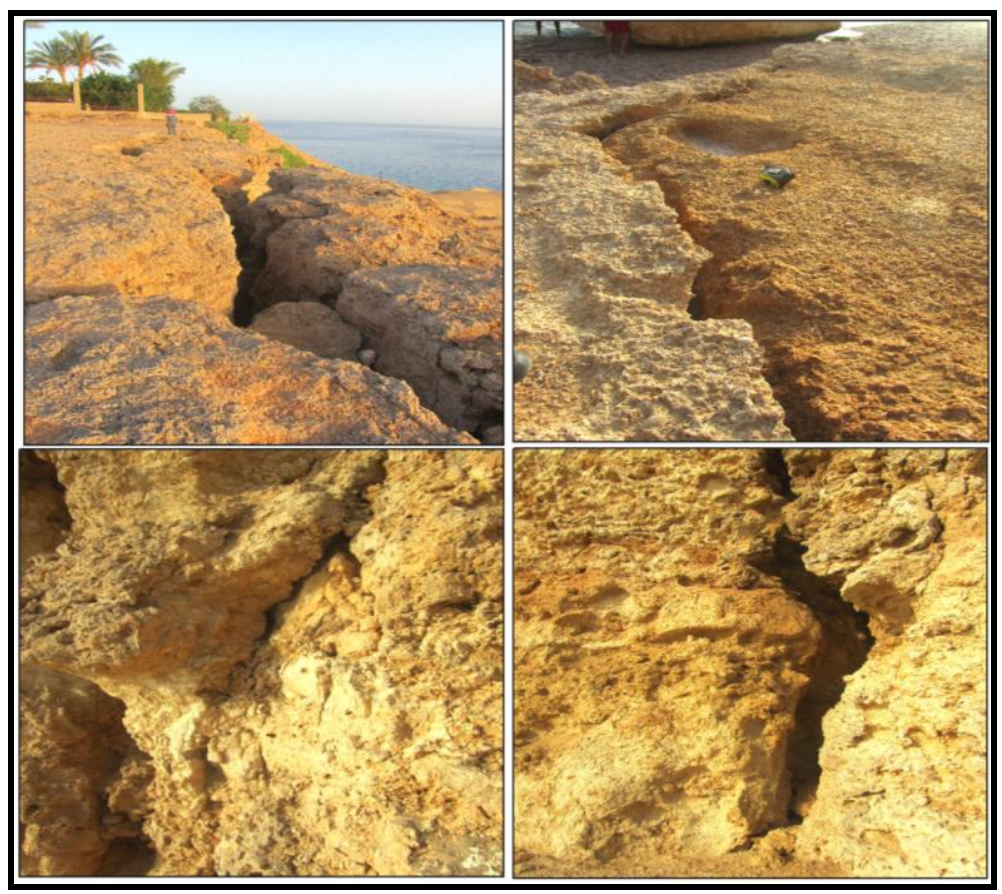

Source: Field study, 2019.

Figure 11. Joint system in the rocks in the study area.

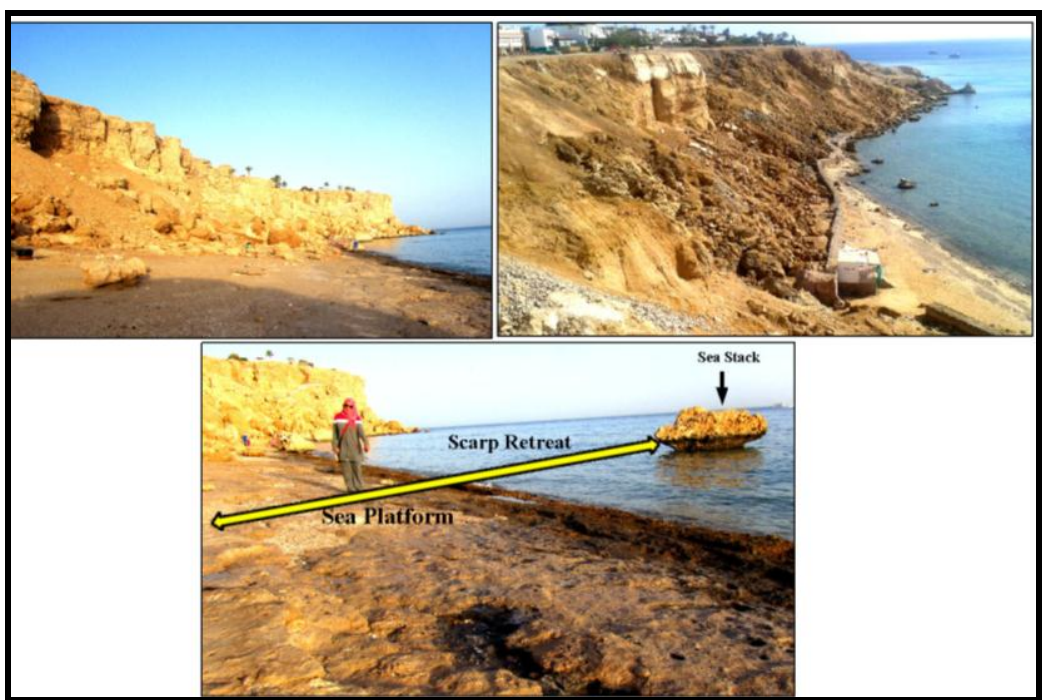

Source: Field study, 2019.

Figure 12. Collapses and rock falling and retreat of the marine scarp and the formation of a marine platform in the study area. 


\section{Second:}

\section{The weathering features inside the rocks of Um Sid Plateau}

The study has relied on two methods to know the weathering features inside rocks which are:

\section{1) The Hydro chemical Analysis:}

The rocks of the marine scarp of Um Sid Plateau includes several salt types where the most important ones are the Chlorides, Sulfates and Bicarbonates as set in Table (7) and which can be explained in details as follows:

Table 7. Hydro chemical Analysis (Salt content \%).

\begin{tabular}{|c|c|c|c|c|c|c|c|c|c|}
\hline \multirow{2}{*}{\multicolumn{2}{|c|}{$\begin{array}{c}\text { Sample } \\
\text { Code }\end{array}$}} & \multirow{2}{*}{$\begin{array}{c}\text { E.C. } \\
\text { mmhos/ } \\
\text { cm }\end{array}$} & \multirow{2}{*}{$\begin{array}{c}\text { TDS } \\
\text { "PPm", }\end{array}$} & \multicolumn{6}{|c|}{ Hypothetical dissolved salts "\%" } \\
\hline & & & & $\mathrm{KCl}$ & $\mathrm{NaCl}$ & $\mathrm{CaSO}_{4}$ & $\mathrm{Na}_{2} \mathrm{SO}_{4}$ & $\mathrm{MgSO}_{4}$ & $\mathrm{CaCO}_{4}$ \\
\hline West & 1 & 25.11 & 30214 & 6.48 & 35.98 & 28.21 & 22.50 & 5.34 & 1.49 \\
\hline South & 2 & 29.34 & 33543 & 5.65 & 33.87 & 38.63 & 19.06 & 2.11 & 0.68 \\
\hline East & 3 & 20.17 & 24621 & 3.76 & 30.67 & 33.01 & 20.17 & 9.76 & 2.63 \\
\hline East & 4 & 18.27 & 21954 & 8.45 & 40.13 & 22.39 & 21.33 & 3.96 & 3.74 \\
\hline \multicolumn{2}{|c|}{ Average } & 23.2225 & 27583 & 6.085 & 35.1625 & 30.56 & 20.765 & 5.2925 & 2.135 \\
\hline
\end{tabular}

Source: Laboratory analysis in the Central Laboratories of the Egyptian Geological Survey, 2019.

- The Total Dissolved Salts: The total dissolved salt content in the samples of the study area ranges from $21954 \mathrm{ppm}$ (Part per million) in the east and $33543 \mathrm{ppm}$ in the south of the scarp with a general average of $27583 \mathrm{ppm}$.

- The Choloride Salts: In general, there is a rise in the percentage of the Sodium Chloride concentration in the rocks of the study area since the general average of its concentration percentage in the samples is $35.16 \%$ which constitutes a great hazard. This is due to its high ability at absorbing humidity from the atmosphere and transmitting it through the rock pores. The surface sediments of these salts have porosity that enables them to absorb the air humidity once more and migrate them in the form of salt solutions inside the rock texture. The repetition of this process increases the pressure on the rock texture leading to its disintegration and exfoliation (AlMahary, 2006). The main source of increasing the concentration of Sodium Chloride salt is the sea water (as sea splash and sea spray).

- Sulfate Salts: The general average of the percentage of Sodium Sulfates in the study area samples is $20.7 \%$ and it ranges between $19.06 \%$ and $22.50 \%$. Its hazard lies in its continuous transformation 
between the dry phase and the watery one resulting in the increase in the size of its crystals and leading to its disintegration, damage and weathering (Kamh, 2011). However, the general average of the concentration percentage of Calcium Sulfate $\left(\mathrm{CaSO}_{4}\right)$ in the study area is $30.56 \%$ as it ranges from $22,39 \%$ to $38.63 \%$. As to the general average of Magnesium Sulfate $\left(\mathrm{MgSO}_{4}\right)$, it is $5.29 \%$ and it ranges from 3.96 to $9.76 \%$.

The above mentioned shows that there are concentrations of the sulfate and chloride salts with high percentages in the study area. This had an influence on the formation of an increasing internal pressure on the rock texture and its resistance degree. This has caused strong mechanical pressures and chemical damage on the surfaces of the study area rocks leading to their dissociation and collapse.

\section{2) The Microscopic Analysis (The Electronic Microscope):}

The importance of the Electronic Microscope springs from its role in specifying the results and features of collapse inside rocks as displayed in Figure (13): The analysis of the Electronic microscope results shows as follows:

- The First Sample: It is located to the west of the marine scarp. It consists of limestone that consists of Microspar 5-10 micron; It is full of some fossils, Sodium Chloride salts (the white parts), gaps full of sparite, varied size gaps that are entangled and empty as a result of weathering; taking a round and linear shape and it helped in gathering humidity and salts inside it so that the rock became weakened and disintegrated.

- The Second Sample: It is located to the south of the marine scarp where a strong dissociation is apparent consisting of sparite with gaps full of rock granules.

- The Third Sample: It is located to the east of the marine scarp. It is a Microspar with middle size gaps full of sparite and minute fossils (Foraminifera) and it consists of Micrite (soft calcareous substances) in addition to the separation of granules of rocks with the size of 50 micron.

- The Fourth Sample: It is located to the east of the marine scarp and it consists of Microspar, sparite, giant gaps with variant shapes having sulfate salt crystals and some Halite along with some connected rifts. In addition, it consists of big size sparite with huge gaps having Sulfate salt crystals with some Halite and some minute rifts. 


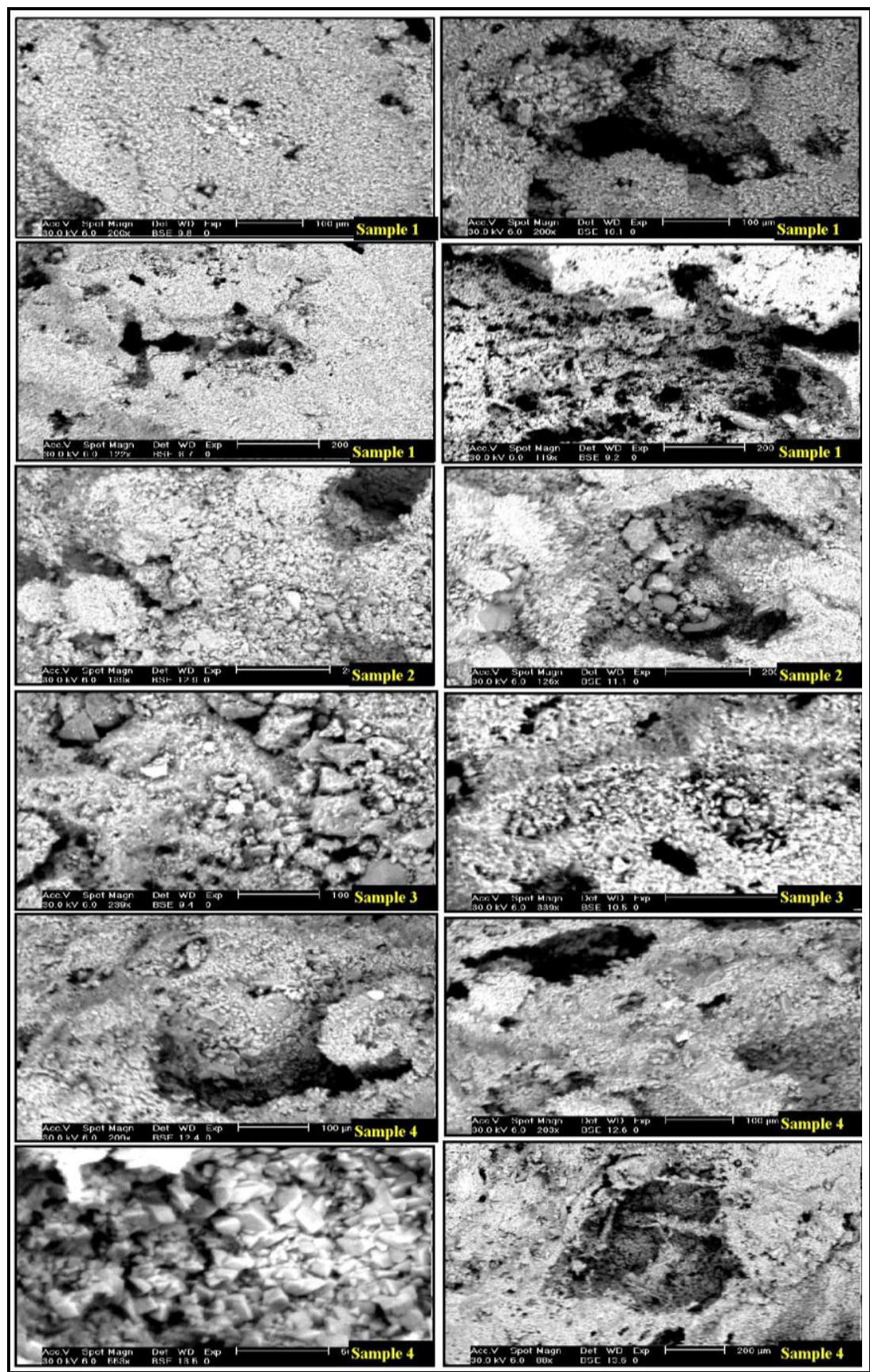

Source: Laboratory analysis in the Central Laboratories of the Egyptian Geological Survey, 2019.

Figure 13. The Weathering Features inside the rocks of the marine scarp of Um Sid Plateau (Using the Electronic Microscope). 
The above analysis shows that the marine scarp has been influenced by the weathering process which appeared in the form of disintegration of the texture constituents and the existence of rifts and gaps between the rock ingredients and the dissolution of some crystals with the existence of several accumulating salts. Besides, the gaps inside rocks have activated the weathering action. At the same time, it denotes that rocks have been influenced strongly by weathering. This led to the appearance of several geomorphological phenomena in the rocks of the marine scarp represented in the dissociation and disintegration, exfoliation, solution pits, and Conical Talus.

\section{Third:}

The Geomorphological Phenomena Resulting from the Weathering Process in the Study Area:

There are several geomorphological phenomena resulting from weathering in the marine scarp of the Um Sid Plateau. These phenomena include ones related to chemical weathering and others related to mechanical weathering. Here is a display of some of these phenomena (Figure 14):

\section{1) Dissociation and Mass Separation:}

It is represented in the break of the body of the rock and its division into masses along the extension of joints and separation surfaces which rupture its parts. Such dissociation is widespread in the marine scarp of Um Sid Plateau (Figure 14); which is an indication and proof of the strong weathering especially the mechanical because of its consisting of limestone and the spread of streams among these masses helping to collect the surface water or sea water or irrigation water inside them causing their collapse. No part of this scarp is free from this phenomenon; the main reason behind this is the system of the horizontal and vertical joints and the constituents of the limestone. However, there is an obvious increase in the south of the scarp. In most cases, fraction takes place nearly in the middle of the mass so that small rocky masses appear (Figure 13). The maximum length of these rocks in the study area ranges from about 0.50 to 3.0 and their height, which vertically extended upon the length extension, ranges from 0.5 to $2.5 \mathrm{~m}$. 


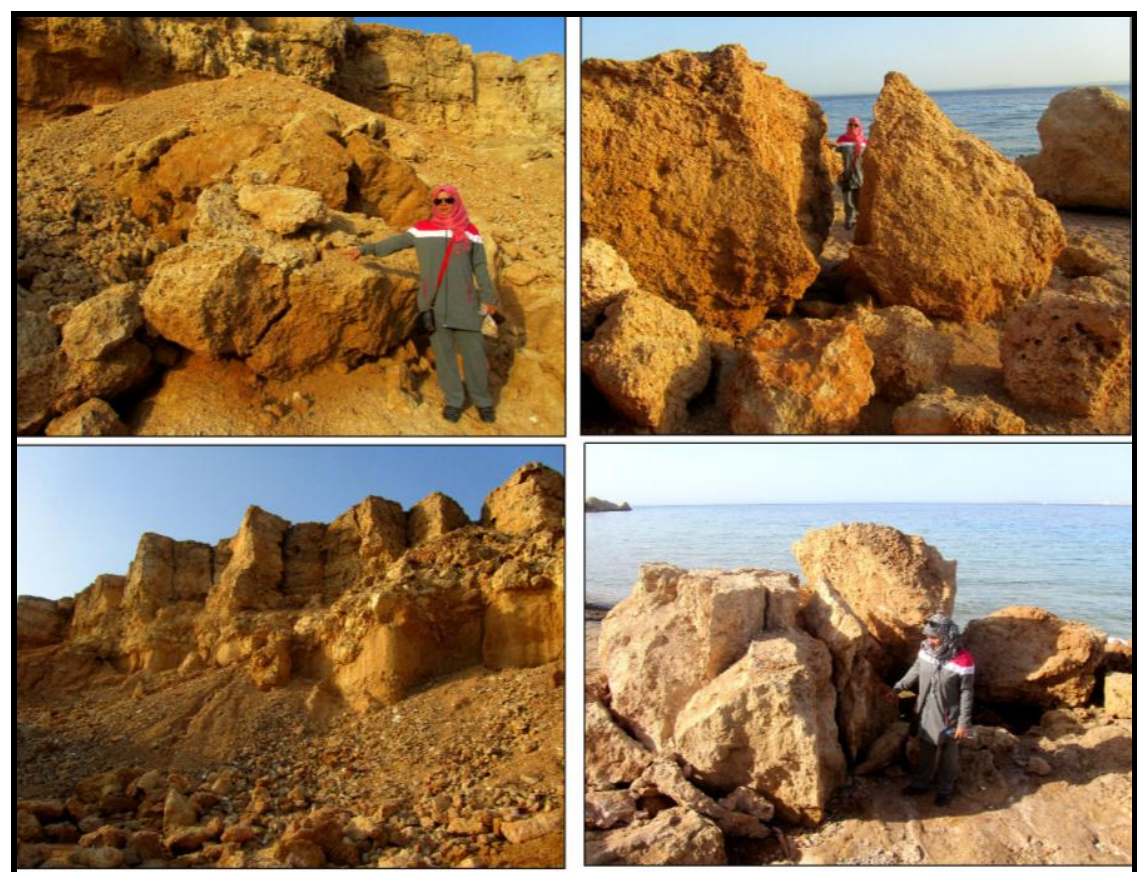

A. The spread of the mechanical weathering phenomenon (dissociation-disintegration-conical talus) in the marine scarp of the Plateau.
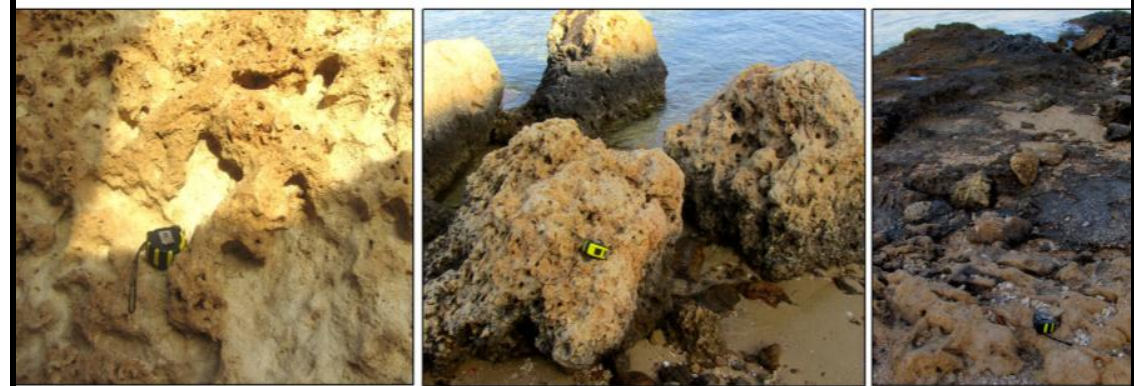

B. The spread of the chemical weathering phenomenon (solution pits) in the marine scarp of the Plateau and the spread of the dissolution holes and algae on the marine pavement.

Source: Field study, 2019.

Figure 14. Some of the phenomena resulting from weathering in the marine scarp of Um Sid Plateau. 


\section{2) The Granular Disintegration:}

The phenomenon of granular disintegration appears as a result of the variation in the types of minerals constituting rocks as the one rock consists of several minerals. Accordingly, variant rates of extension inside rocks exist causing many pressures inside the rocks which result in minute breaks and disintegration of granules (Ollier, 19984). The diameter of the disintegration granules does not exceed $5.0 \mathrm{~m}$. Thus, these granules represent the hard sediments in the conical talus as they result from the mechanical weathering action as a result of the pressure among crystals and their disintegration as verified by Thin-Section Microscope.

\section{3) The Conical Talus:}

Conical Talus constitute one of the geomorphological phenomena that formed mainly by the weathering processes especially dissociation and mechanical disintegration of rocks. They are granular sediments and clustered rock masses upon the hazard slopes. This phenomena is spread in various areas of the study area especially the south and west of the scarp. Slope Talus consists of different groups of sediment sizes ranging between the very soft and the rock masses at the hazard cones (Figure 14). This led to the increase in its vertical extension noting that this thickness decreases gradually till it vanishes completely heading upwards in the study area.

\section{4) Cavitation and Bee Hives:}

Cavitation or the tafoni gaps are cavities that take place in rocks because of water action since water performs dissolution inside rocks. Therefore, the tafoni gaps are always at the bottom of the area. It resulted from the unification of the bee hives to form big size gaps (Cavities) as the solution pits are made with the same way by which the tafoni gaps are made although they differ in size and shape. They appear as pits or small size holes that do not exceed few centimeters. The dissolution process is widespread at the interface of the marine scarp which was registered during the field study and the Thin -Section Microscope where some solution pits (minute gaps) are obvious. They verify the existence of chemical weathering resulting from the splash of sea water loaded with salts. As to the interface of the Plateau, it is full of solution pits (Figure 14). The morphometric analysis of the dissolution pits reveals that they differ in their shapes; some are oval, some are circular, others are linear and irregular. The length of these holes ranges from 0.5 to $10.0 \mathrm{~cm}$. However, the average of their width does not exceed $5.0 \mathrm{~cm}$ while the average of the depth is $5.0 \mathrm{~cm}$. 


\section{5) Exfoliation:}

It is one of the geomorphological phenomena resulting from the weathering process whose inception is due to several entangled and collaborated factors. The shape of these scales is due to the nature of the rock surface pores, temperature, surrounding relative humidity, and evaporation which appear in the study area in several locations. The field study reveals the spread of thin strips that appear in the scarp rocks with thickness that does not exceed $2 \mathrm{~cm}$ mostly.

\section{6) Platforms:}

The different weathering processes whether mechanical or chemical have a main role in the emergence of marine Platforms in the study area because of the weakness of the marine weathering factors especially the hazard waves. Degradation and back word retraction of rock surface took place as a result of the succession of wetness and dryness, the dissociation, disintegration and dissolution of the limestone rocks that are spread in the rocks of the Plateau. They are spread along the marine scarp especially the southern side. The length of the marine Platform ranges between 3 to 120 meters and there are widespread solution pits and rock masses as well as the multicoloured algae (Figure 14).

\section{Fourth:}

The Hazards resulting from the weathering processes in the Marine Scarp and their protection methods.

Weathering helped in weakening rocks and in contributing to the processes of dissociation and collapse of rocks in the study area. The problem of rock falling is one of the problems resulting from the weathering process in the marine cliffs especially in the interface of the Um Sid Plateau which caused a direct hazard upon the human activities especially the touristic villages and resorts in the study area. Huge rock falling was registered in the western and southern marine scarp of the Plateau (Figure 15) where chalets and touristic activities are spread.

Based upon the previous analysis of the weathering processes and the fields study, the marine scarp of Um Sid Plateau represents a hazard upon all the touristic activities that take place beneath it as well as the touristic and habitual activities that are spread on its surface and which is near to the scarp; noting that the degree of hazard differs from a location to another especially in the area beneath the scarp as the field study shows (Figure 16) and (Figure17). 


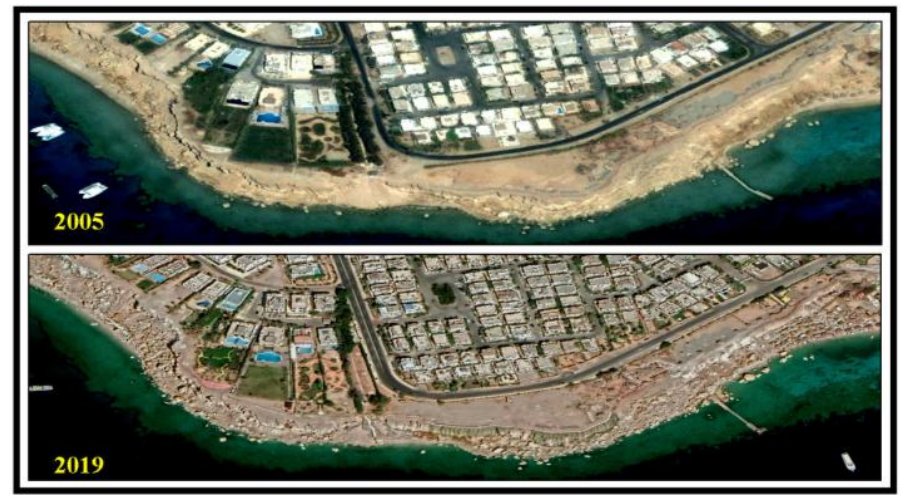

Source: Google Earth

Figure 15. The rock falling from the marine scarp of Um Sid Plateau.

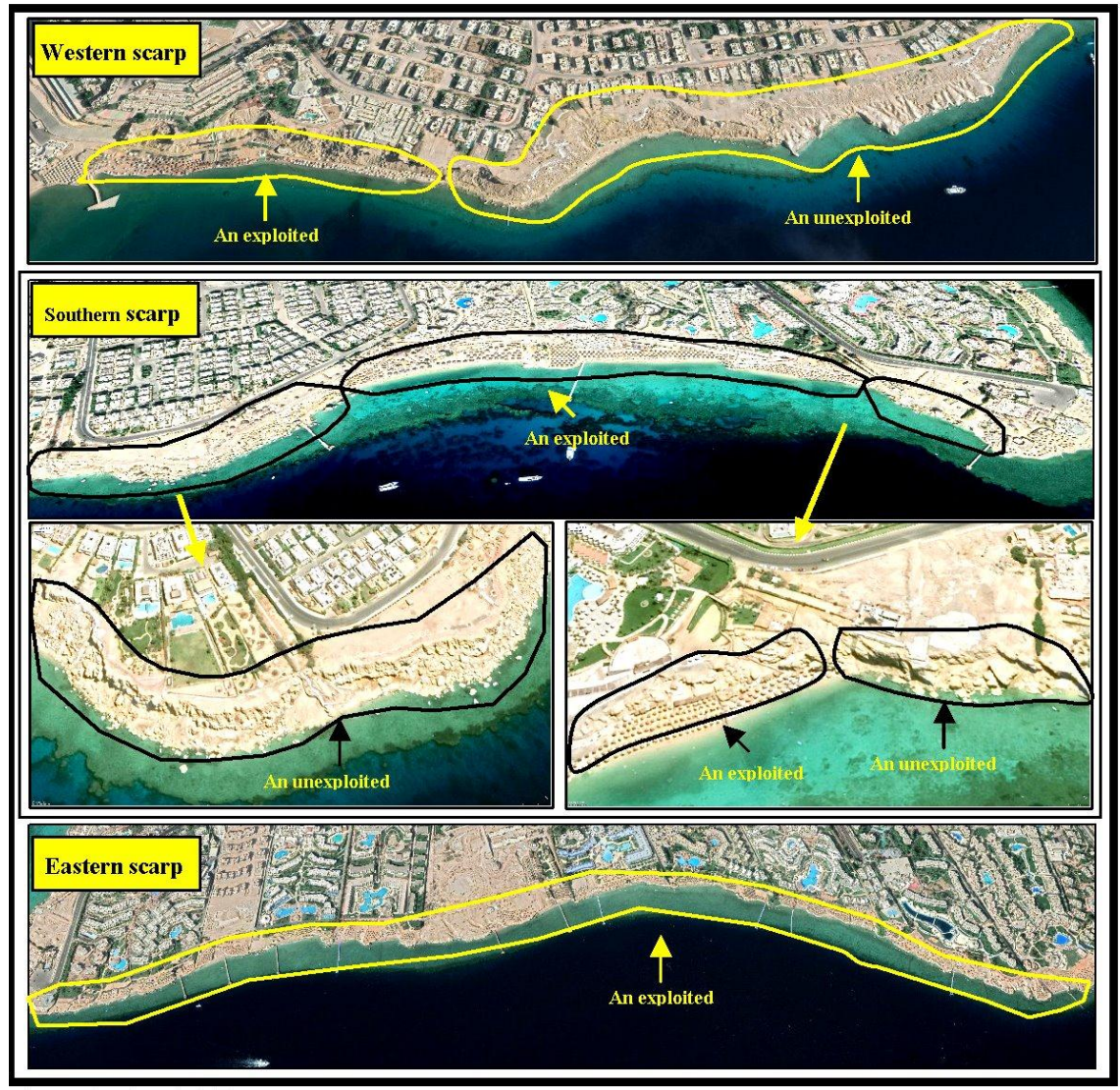

Source: Google earth, 2019.

Figure 16. The exploited and unexploited areas in front of the marine scarp of Um Sid Plateau. 


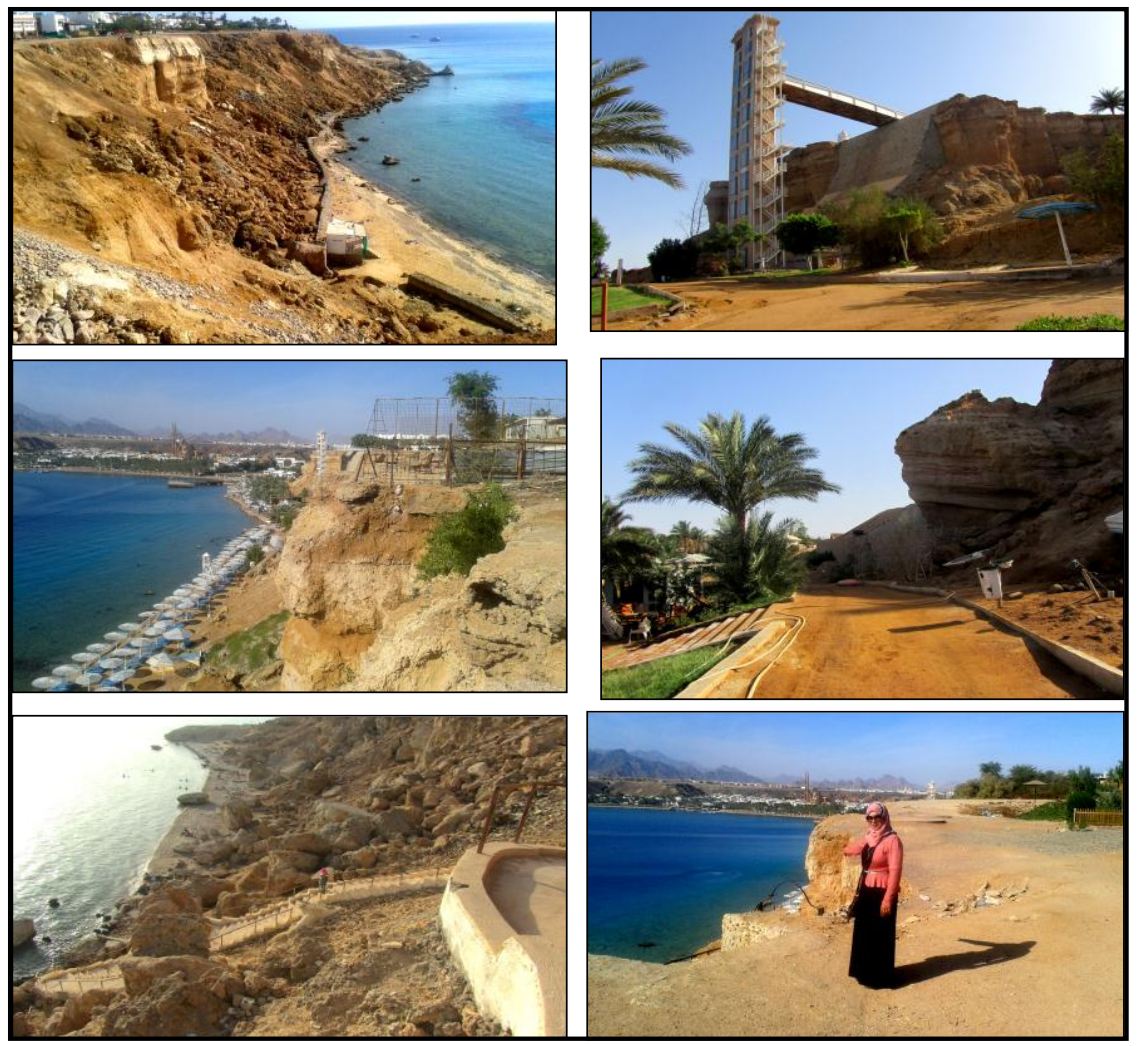

Source: Field study, 2019.

Figure 17. Several touristic activities are exposed to the hazard of rock falling from the marine scarp of Um Sid Plateau.

- The Western Scarp: Its length is $1.7 \mathrm{Km}$ while more than $29 \%(0.5$ $\mathrm{Km}$ ) from its total length is not exploited in the human activity. It is the least used scarp. As to the rest of the percentage which is $71 \%(1.2$ $\mathrm{Km}$ ), it is without any touristic activity. This is because of the frequent falling and the abundance of big size masses because of the strength of the weathering processes and the nearness of the scarp and ability of masses to reach the sea.

- The Southern Scarp: Its length is $1.6 \mathrm{Km}$ where about $56 \%$ (0.9) of its total length is exploited in touristic activity. However, despite the exploitation of half of the scarp length, human activity in this area is in great hazard since this area is the most exposed area to the hazard of rock falling because of the extension of the activity to the scarp itself (Figure 17).

- The Eastern Scarp: Its length is $2 \mathrm{Km}$. It is one of the most exploited scarps in touristic activity since it exceeds $95 \%$ of the scarp length 
because of the remoteness of the scarp from the sea. This paved the way to the spread of the touristic activity. This is beside its hazard level and the weakness of the weathering action in it.

- The Southern Scarp: It is similar to the western marine scarp in the degree of hazard. Its length is $1.6 \mathrm{Km}$ where about $56 \%(0.9)$ of its total length is exploited in touristic activity. However, despite the exploitation of half of the scarp length, human activity in this area is in great hazard since this area is the most exposed area to the hazard of rock falling because of the extension of the activity to the scarp itself (Figure 17).

\section{Conclusion:}

\section{1- The Results:}

The study of the geomorphological evaluation of weathering on the marine scarp of Um Sid Plateau in the south of Sinai concluded with the following results:

- Several climatic factors had collaborated to weaken rocks in the marine scarp of the Um Sid Plateau and they increased their response to the mechanical and chemical weathering processes so that the marine scarp became exposed to dissociation, disintegration and decay.

- Sea water is an important source of humidity and dissolved salts in the study area whose direct influence has reached $15 \%$ of the height of the marine scarp through waves and tides. It may indirectly reach $100 \%$ through water splash and sea spray which is transmitted by waves or winds. It is a common denominator in most of the chemical weathering processes whether the oxidative stress processes, Carbonization, dissolution or water Hydrolysis.

- Human factors play an outstanding role in the weathering action process on the marine scarp of the Plateau because of the excessive extravagance in the irrigation of gardens. This is beside the sewage leakage in the plateau so that plants grow inside it especially at the, marine scarp. The production of organic acids from the rotten plants led to the increasing porosity and to the widening of cracks and splits more and more in the marine scarp to end in disintegration and decomposition.

- The whole scarp is exposed to weathering whatever the degree to which it is affected since the scarp consists of limestone rocks which are the most responsive types of rock to dissociation and dissolution due to weathering, resulting in granules with varied size in the study area, especially the southern and western sides of the scarp. This is beside the appearance of several geomorphological phenomena in the rocks of the 
marine scarp which are represented in dissociation, disintegration, conical talus, exfoliation, cavities, solution pits and marine platforms.

- The problem of rock falling is one of the most important problems resulting from the weathering process, vertical joints and faults structure geology in the marine cliffs precipice especially the interface of Um Sid Plateau which caused a direct hazard upon the human activities especially the villages and touristic resorts. Rock falling was registered strongly upon the western and southern marine scarp in the plateau in which chalets and touristic activities are widespread.

\section{2- Recommendations:}

The field study has registered a group of the protection methods from the rock fall hazard which results from the weathering action in the study area (Figure 18) as follows:

- Blocking walls from rocks and cement (There is a constructed part on the western side of the scarp). Its main purpose is preventing the arrival of the high tide to the bottom of the marine scarp. Besides, it serves as a blocking wall to prevent the masses and rock granules from reaching human activity.

- The existence of rock and cement lining for some of the scarp sides.

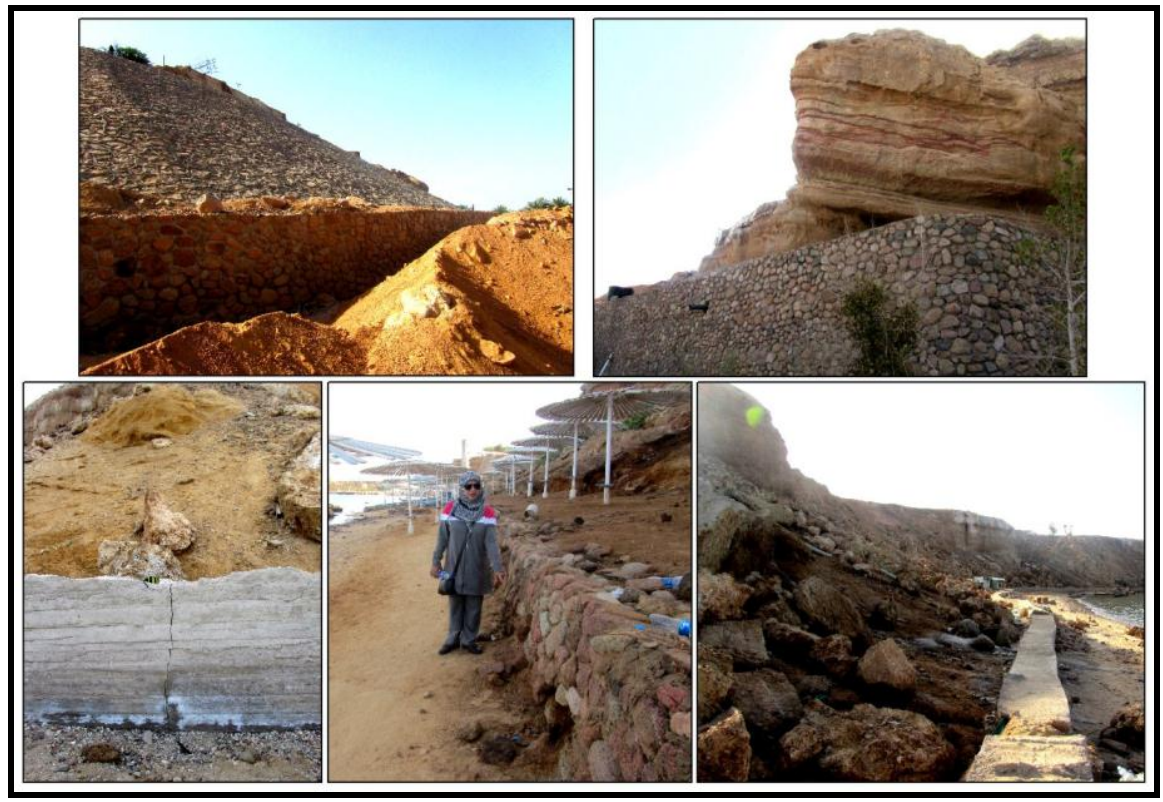

Source: Field study, 2019.

Figure 18. Some of the protection methods from the hazard of rock falling from the marine scarp of Um Sid Plateau. 
The field study pointed out that these means are insufficient for protecting the human activities from the hazard of rock falling. Therefore, the study recommends as follows:

- Using the method of being unexposed to the locations that are subject to hazard, through providing guidance tables that prevent approaching and urban expansion towards the scarp.

- Removing the unstable rocks and talus in the area to reduce the fall hazard.

- $\quad$ Increasing the blocking walls (rocks and cement)

- Increasing the scarp lining using rocks and cement so that it takes the same sloping degree of the slope.

- Using rods to fasten rocks since this method relies on increasing the vertical pressures upon the possible collapsing surfaces to increase its ability at bearing shear stresses and the slope stability.

- Scaling the slopes till reaching the angle of stability through reducing the degree of sloping. 
Appendix 1. Salt susceptibility index limits and its interpretation ( $\mathrm{Yu}$ and Oguchi, 2010).

\begin{tabular}{|l|l|}
\hline \multicolumn{1}{|c|}{ SSI } & \multicolumn{1}{c|}{ Interpretation } \\
\hline $0 \leq \mathrm{SSI}<2$ & Exceptionally salt resistant \\
\hline $2 \leq \mathrm{SSI}<3$ & Very salt resistant \\
\hline $3 \leq \mathrm{SSI}<6$ & Salt resistant \\
\hline $6 \leq \mathrm{SSI}<12$ & Salt prone \\
\hline $12 \leq \mathrm{SSI}<16$ & Very salt prone \\
\hline $16 \leq \mathrm{SSI} \leq 20$ & Exceptionally salt prone \\
\hline
\end{tabular}




\section{References}

1. Abdel Megeed, A. O. A., (2012): The Area of Ras Nasrani Between Al Aat Eastern wadi and Um Adawy-A Geomorphological Study, Unpublished M.Sc. Thesis, Department of Geography and Geographical Formation System, Faculty of Arts, Alexandria University:151.

2. Abdel Tawab, S., (2012): Rock Fall Failure Model Practical Example of Umm Sid Plateau-Sharm El Sheikh area, Egypt, International Journal of Scientific \& Engineering Research, Vol. 3, Issue 10, October-2012 1,ISSN 2229-5518:1-10.

3. Abdel-Halim, A.M., Abo EL-Khair, E. M, Fahmy, M. A, Sridah, M. A., (2007): Environmental Assessment on the Aqba Gulf Costal Waters; Egypt, Egyptian Journal of Aquatic Research Issn: 1687-4285, VOL. 33 NO. 1, 2007: $1-14$.

4. El Mahary, S.A., (2007): Studying the Effect of the Varied Damage Factors on the Ruins of some Monumental Locations in the Kingdom of Bahrain and the Maintenance and Restoration Suggestions as Applied on the Monumental Ruins of Sar, Unpublished M.Sc. Thesis. Faculty of Antiquities, Cairo University.

5. Eladawy, A., Nadaoka, K., Negm, A., Abdel-Fattah, S., Hanafy, M., e, Shaltout, M., (2017):Characterization of the Northern Red Sea's Oceanic Features with Remote Sensing Data and Outputs from a Global Circulation Model, Oceanologia 59, 213-237.

6. Farmer. W. (1968): Engineering Properties of Rock, London (Barnes and Noble, New York).

7. Gharbi, S.H., Al barakati A.M., Al saafani, M.A., Saheed P.P., and Alraddadi T.M.,(2018): Simulation of tidal hydrodynamics in the Red Sea using Coherens Model, Regional Studies in Marine Science 22 : 49-60.

8. Kamh, G.M.E., (2007): Petrographic, Geotechnical and Durability Investigations of Sandstone from El-Silsila Nubian Quarries used for Restoration, A case Study. International Journal for Restoration of Buildings and Monuments, 13(1):39-56.

9. Kamh, G.M.E., (2011): Salt Weathering on Buildings and Antiquities in some of the World Counters, Menoufiya University Press: 178.

10. Mahsoub, M.S. (1991): Costal Geomorphology, Dar El Thaqafa for Publishing, and Distribution, Cairo: 119.

11. Manasrah, R., Abu-Hilal, A., and Rasheed, M.(2019): Physical and Chemical Properties of Sea water in the Gulf of Aqaba and Red Sea, Springer Oceanography, 41-73.

12. Ollier, C. (1984): Weathering, Second edition, Longman Inc., New York: 19.

13. Raheel, F.Z., (2019): The Geomorphology of Marine Cliffs and There Related Features at the Area of Ras El- Hekma, Between Ras EL-Gharqan and Ras Hewalah, Ph.D. Thesis, Faculty of Education, Alexandria University:35-36.

14. Saber,A.I.,(2017):The Features of Rock Weakness and Their Geomorphological Role in the Formation of the Slopes Talus on the Two Sides of Sharm El-Sheikh - Dahab Road, Wadi of Kid, South-East Sinai, Bulletin of the Egyptian Geographical Society, Vol : 105:35-52. 
15. Salama, Z.H.R., (2016): Climate and its Environmental Effects on South Sinai, Study of the Applied Climatic Geography, Unpublished M.Sc. Thesis., Department of Geography, Faculty of Arts, Cairo University.

16. Youssef, A.M., Maerz, H., and Hassan, A.M., (2009): Remote Sensing Applications to Geological Problems in Egypt: A case study, Slope Instability Investigation, Sharm El-Sheikh/Ras-Nasrani Area, Southern Sinai, Landslides 6:353-360, DOI 10.1007/s10346-009-0158-3.

17. Yu, S. and Oguchi, C.T., (2010): Is Sodium Sulfate Invariably Effective in Destroying any Type of Rock? Natural Stone Resources for Historical Monuments, Priley and Torok "eds" Geological Society, London, Special publication, v.333:43 - 58 . 


\section{التقييم الجيومورفولوجي للتجوية على الحافة البحرية

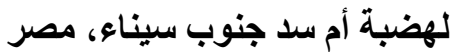

\section{د. دنال سمير شلبي متولي}

مدرس الجيومورفولوجيا ونظم المعلومات الجغرافية

كلية الآداب - جامعة بورسعيد

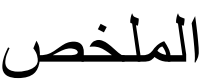

تضافرت البيئة الداخلية والخارجية لتصبح التجوية لها دورا رئيسيا في إضعاف صخور الحافة

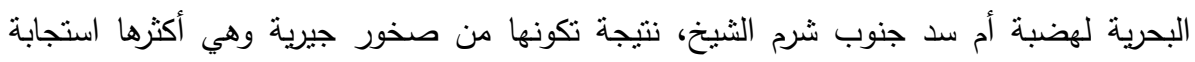

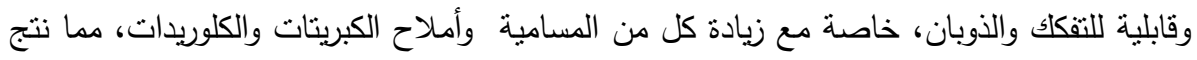

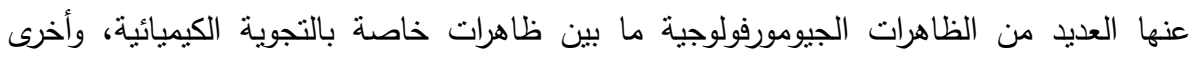

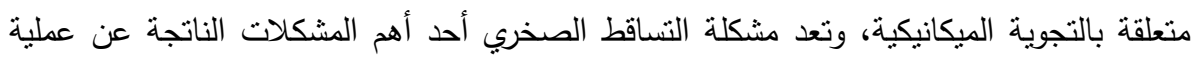

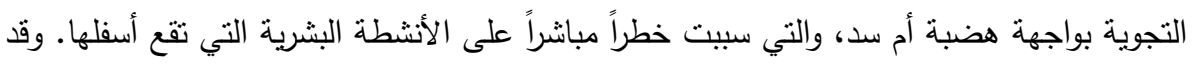
اعتدت الدراسة على العديد من التحليلات البتروفيزيائية والكيميائية والميكروسكوبية لمعرفة مظاهر التئية الضعف ومدى تأثيرها في الحافة.

الكلمات المفتاحية: التجوية، تحليلات معلية، حافة بحرية، الاخطار. 